\title{
Civil Servant Borrowing Practices: A Determinant of Poverty in Zimbabwe
}

\author{
Tan Zhongming \\ School of Economics and Finance, Jiangsu University \\ No. 301 Xuefu Road, Zhenjiang, Jiangsu, P.R. China \\ E-mail: tzymyx@mail.ujs.edu.cn
}

Tinashe Mangudhla (Corresponding author)

School of Economics and Finance, Jiangsu University, P.R. China

E-mail: tmangudhla@gmail.com

Reginald Masimba Mbona

School of Economics and Finance, Jiangsu University, P.R. China

E-mail:rmmbona@yahoo.com

Received: April 13, 2020 Accepted: May 12, 2020 Published: May 19, 2020

doi:10.5296/ber.v10i2.16832ＵRL: https://doi.org/10.5296/ber.v10i2.16832

\begin{abstract}
In assessing microfinance institutions (MFIs) and civil servants' perspectives on borrowing in Zimbabwe, we examine the purpose and rationale of MFIs establishments. Thus, in an attempt to understand the reason behind high borrowing, we also considered loan terms, the nature of loans issued, and the uses of MFIs borrowed funds among households. Driven by the exploratory approach, qualitative research involving semi-structured interviews and observation methods were applied in this study. Using, the purpose of the loan, pricing of loans, repayment terms, and loan terms, interview questions were designed and conducted. Our results show that MFIs loans are: short term loans, income (salary) based; and, these loans are mainly for immediate household consumption needs not an investment. This study also indicates that loan application requirements are more favorable for employed households, especially public sector employees. Even though civil servants have a better advantage in accessing MFIs loans, in the long run, they are likely to remain in poverty; since their
\end{abstract}


purpose of borrowing is geared towards family expenses. Also, MFIs prevailing interest rates (high), evidenced with shorter repayment periods, reflect their failure to pull borrowers out of poverty; however, creating an interdependence syndrome of continuous borrowing. Since we focused on lending practices of households, our results serve as a basis of a joint policy formulation in combating poverty. Thus, understanding poverty through the borrowing of employed citizens aids in grasping the interconnectedness of sectors; which, is an essential tool for sustainable development and strategic planning.

Keywords: Microfinance institutions, Loans, Households, Civil servants, Borrowing, Poverty reduction, Zimbabwe

\section{Introduction}

The introduction of microfinance has raised high expectations for poverty reduction in developing countries (UN, 2013), as it has been one amongst many efforts that are being made by governments and institutions to overcome it. In this context, microfinance serves as a lifesaving tool because it provides financial and social services to socially disadvantaged and excluded members who do not have access to traditional financial services from registered banks, (Iqbal, Nawaz, \& Ehsan, 2019; Jain \& Economics, 2009). The question however as many other poverty relief programs is whether they have been able to accomplish their goal or they have ended up exploiting the very same targeted people whose earnings are below the poverty datum line.

In Zimbabwe, from 2010 through 2019 the number of MFIs registration and the patronage of their tailored financial services and products have been gradually increasing on yearly basis during years of economic hardships (Dube \& Matanda, 2013; ZAMFI, 2018). For instance, during the first six months of 2018, 19 newly MFIs were registered by the regulator making a total of 194 MFIs in operations; harmoniously, as at 31 December 2018, a total of 205 MFIs were operational in the country, (Chakanyuka, 2019; Moyo, 2018).

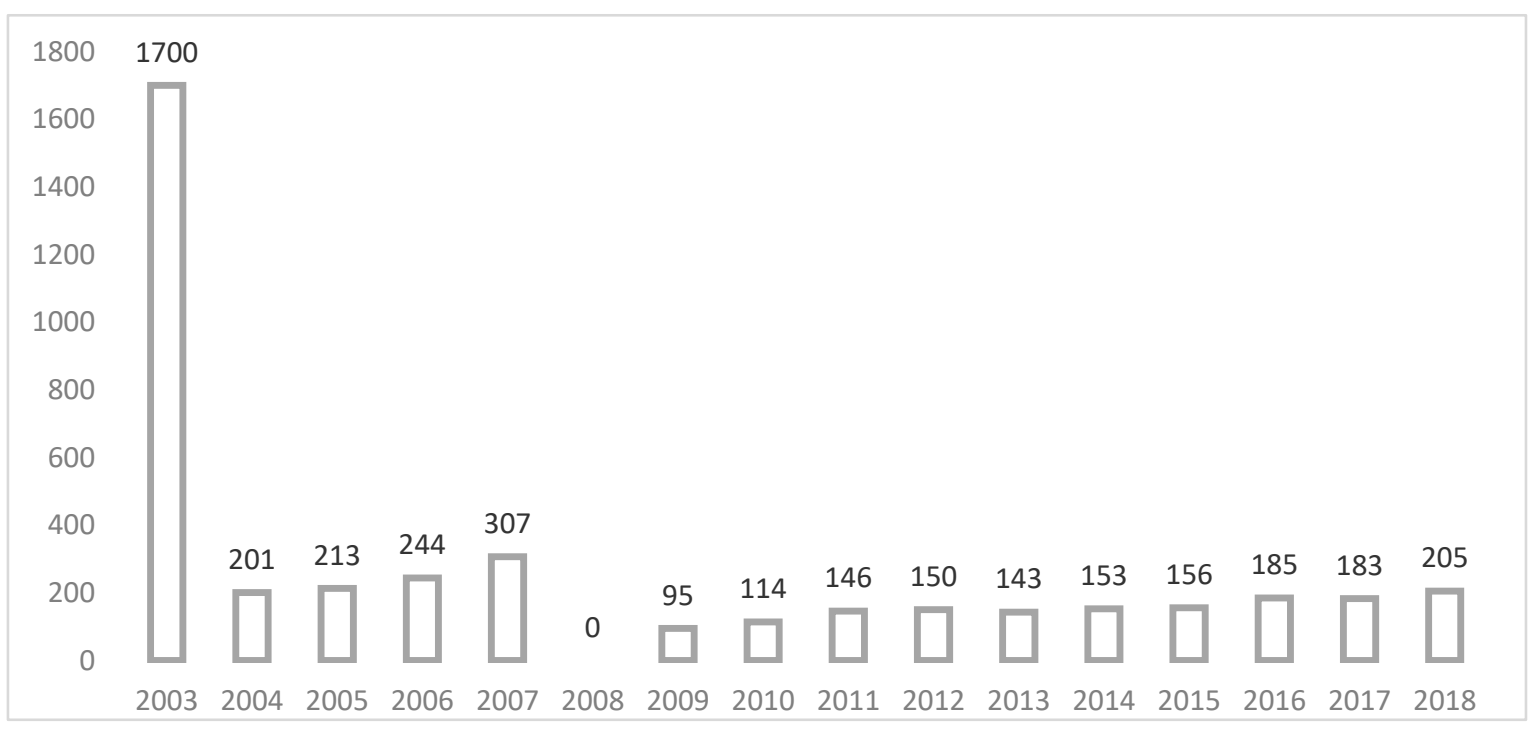

Figure 1. Shows the number of registered MFIs in Zimbabwe from 2007-2018 
Initially, microfinance institutions provided financial services only to low-income clients, but have now expanded to include financial services to individuals including small-micro enterprises who were often excluded from mainstream financial services; (Abor, 2016; Brière \& Szafarz, 2015; Cull, Demirgüç-Kunt, \& Morduch, 2013; UN, 2013). This unprecedented growth has increased the attractiveness of microfinance and served as a bridge to reduce poverty and reduce the financial inclusion gap in some parts of the world (Copestake, 2019; Yimga, 2018). Under trying circumstances, Zimbabwean microfinance players had to ensure maximum capitalization on the market with prevailing liquidity crisis (cash shortages), high cost of living in the country; and, the majority of working-class especially government workers earning below the poverty datum line. The MFI outreach in Zimbabwe is reported to be 1.32 percent of the global loan outreach which amounts to \$115, 6 million, (Moyo, 2018). This proves that microfinance tends to thrive in developing countries where unemployment and poverty are rising, (Klinkhamer, 2009). In a report on Zimbabwe (Chakanyuka, 2019; Mhlanga, 2018), proposed that the growth of MFIs is connected to the majority of citizens who have no access to formal banking facilities, which however is not the case in Zimbabwe because the majority of workers have their salaries pass through traditional banking institutions and still borrow more from MFIs.

\subsection{Current Problems in Zimbabwe}

In an attempt to support the multi-currency and to end cash shortages, in 2016, bond coins and notes were introduced to operate in conjunction with other foreign currencies, (Ndamu \& Tatira, 2016; NewsDay, 2019). Failure to resolve the cash shortage, another currency RTGS dollar (Real-Time Gross Settlement), was introduced as the first step towards a new currency aiming to stabilize an economy plagued by inflation and widespread cash shortages, (Banya, Toyana, Stonestreet, \& Boyle, 2019). It is key to note that the introduction of these new currencies contributed to the rising of production cost since businesses were preferring to transact in foreign currency which was used to import raw materials. However, the foreign currency was scarce among banking institutions and easily available on the black market (illegal money changers on the streets) at higher rates. In such an environment households had to find an alternative way to finance their consumption which paved a way for external borrowing to cover costs like medical care, educational expense, among other expenses. Therefore, making MFIs the preferred choice of many due to its flexibility and the aim to give short term loans aimed at alleviating poverty among individuals with fewer collateral demands.

Low income received among the working class especially the civil servants has caused a positive shift towards the usage of MFIs in particularly. These civil servants are being paid salaries which are far much lower than those in the private sector at the same time well below the poverty datum line; and, their fringe benefits and other incentives offered by the government to its employees are far below as well. The inability of civil servants to attain a minimum standard of living and low quality of life they desire requires one to search for external funding, thus making MFIs borrowing a preferential option.

In response to the liquidity constraint, the Reserve Bank has adopted a series of policy 
measures aimed at alleviating cash flow problems, including the importation of liquidity, the promotion of the use of plastic currencies, and cash withdrawal limits (Munyanyi, Diza, \& Gumbo, 2017; R.B.Z, 2016a). However, even though the use of cashless payment channels increased in the economy, the demand for cash and households' willingness to use cash continued, since goods and services were much cheaper when purchased with cash as compared to plastic currencies. Mainly because of tax levied by the government for all online transactions above a USD10 (Dalu, 2018). This has also led households to sources for short term cash funds for consumption purposes and now targeting MFIs.

\subsection{Research Gap}

We want to investigate where most MFIs are located. Their distribution density is key in highlighting what is pushing their establishment as the two, that is, the rural areas and the urban areas, having different uses of money and liquidity as well as users of the money. Most of the civil servants use these urban areas for their demands such as shopping, medical services, and other household needs which includes accessing funds or banking them. This has been the case for countries such as Zambia, Angola, Botswana, and Tanzania which have seen an increase in MFIs in urban and peri-urban areas.

According to (Mashaya, 2017) citing the Zimbabwe National Statistics Agency the government employs 300000 workers, a number that does not include the police, army, air force, and prison personnel. Therefore, making the government the largest employer in Zimbabwe hence the need to evaluate how civil servants through their payslips have been utilizing the MFIs to increase their liquidity above the basic earning generated through their employer.

Unlike past studies, this research is focusing on government workers who are the main users of the MFIs credit services because of the payslips that are being required by these MFIs in Zimbabwe as assurance for repayment (Mpofu, Mutambanadzo, Oliver, \& Lungisani, 2013). Existing studies in Zimbabwe on MFIs have been conducted on the youths (Mpofu 2018), on small-medium enterprises (Mpofu et al., 2013), and several studies conducted on rural people and women (Mago, 2014b; Tshuma \& Selome, 2014). To the best of our knowledge, a gap exists both in literature and research on the civil servants.

Objectives of the study:

$\checkmark \quad$ To assess the distribution density and coverage of the sector

$\checkmark \quad$ To evaluate the connection between interest and borrowing (amount and period)

$\checkmark \quad$ To investigate the most preferred form of money by borrowers

$\checkmark \quad$ To find how the use of the borrowed funds are spread over either household costs or investments or savings

$\checkmark \quad$ To identify the purpose and reasons for establishing MFIs in Zimbabwe

\subsection{Significance of the Study}

The results of this study will help all players in the financial sectors to understand and focus more on their clients who pose diverse income levels, livelihoods, geographical setting 
among others. For instance, this study will assist managers to have an in-depth understanding of the market they are operating in and will also aid in knowing the customer needs which is an appropriate tool for new product development and customer satisfaction. Also, relying on the information from the interviews, our study will provide answers and further explanations (causes and effects) of financial figures that have been recorded by MFIs in the past decade, making this study relevant for investors (current and potential investors). The findings and recommendations would help the board of directors to identify practices to be avoided or adhered to, to maximize revenue.

The final result on distribution density and coverage of MFIs is expected to increase awareness on the accessibility of finance among the low-income households and SMEs; and, the strategies suggested which will also help the entrants to fully understand the dynamics of the Zimbabwean financial sector.

The government and regulation authorities will get a sector insight on the challenges affecting the users of MFIs at the same time providing first-hand information useable for policy formulation that will steer a strong microfinance sector that will further have a positive effect on employment, meanwhile, eradicating poverty among citizens. Finally, our study being qualitative, it serves the basis for quantitative research especially for developing countries on the subject of MFIs in the future.

The rest of this paper is organized as follows: the review of literature, the theoretical framework and hypothesis; and, methodology. Finally, we look at the discussion of the findings which is followed by a conclusion.

\section{Review of Literature}

\subsection{Microfinance in Zimbabwe}

The central bank of Zimbabwe (RBZ) in 2016 came up with financial inclusion strategy to create profitable and sustainable institutions; thus, microfinance has therefore been presented as a framework for providing capital to 60 percent of Zimbabwe's population living in poverty for the empowerment of individuals and economic players (Mhlanga, 2018; Tapera \& Mbira, 2016). It was hoped that providing micro-credits to banks that could not be banked, would help support savings and investment, consumer smoothing and food security, develop businesses and social cohesion, (Gallagher \& Muzorewa, 2017; Mago, 2014a; Munjenjema, 2017; Tinarwo, 2016).

Commenting on the success drivers of MFIs in Zimbabwe, (Tapera \& Mbira, 2016) concluded that, to succeed, microfinance institutions must consider and invest in appropriate risk management systems and sound information technology systems and innovations, adopt and adapt good corporate governance practices, and participate in employee incentives and employee development programs. Inability to detect operational risks early among these organization has also been evidenced and is connected to the absence of the consumer protection law that governs MFIs and this has been witnessed by the inappropriate adoption of marketing strategies and predatory methods of promoting products, (Mago, Hofisi, \& Mago, 2013; Makuyana, 2017). Many micro-funders are facing early collapse or are on the 
verge of collapse because they cannot detect operational risks in advance.

\subsection{Microfinance in Developing Countries}

Microfinance is considered one of the most effective and important tools for eradicating poverty especially in developing countries; and existing evidence illustrate that microfinance in Africa is developing at all three levels of the financial system - micro (financial services provider), medium (provider of support services); and, macro (policy, regulatory framework, and supervision) which makes the significant contributors to emerging economies financial systems (Mago, 2014a; Mushtaq \& Bruneau, 2019; Samer et al., 2015; Sanfilippo-Azofra, Torre-Olmo, \& Cantero-Saiz, 2019; UN, 2013).

Most profit-oriented microfinance institutions use individual or group loans. Instead of being used for SME investment (due to the larger size), most of these loans are used for consumption or education or health care services especially as they have collateral (Bayai \& Ikhide, 2018; Fall, Akim, \& Wassongma, 2018; Sanfilippo-Azofra et al., 2019). With the participation of microfinance programs, there has been a significant improvement in family health research behaviors and health services, (Bhuiya, Khanam, Rahman, \& Nghiem, 2018; Faruqee, 2010; InM, 2015). This study investigates if this is true for Zimbabwe as well.

Government policies can promote or hinder the development of microfinance. Thus, the impact of microfinance on poverty reduction, policymakers need to implement strategies to promote and create better access to microfinance, which can reduce poverty and improve the well-being of the poor, and the marginalized in the Philippines, (Agbola, Acupan, \& Mahmood, 2017).

In the view of Malaysian MFIs, (Samer et al., 2015), concluded that microfinance does not only help to diversify household income and to alleviate poverty among the women, but microfinance can make a significant contribution to the implementation of the new economic policies (NEP) and new economic models (NEMs), which have guided Malaysia towards a 2020 vision and have fully developed.

\subsection{Operations of MFIs}

Differences in forms of ownership can lead to differences in the strategies and objectives pursued by microfinance institutions, and some microfinance institutions act as non-profit organizations, focusing on providing credit to the poorest on relatively generous repayment terms, (Liñares-Zegarra \& Wilson, 2018). Unlike in other developing countries, where some of the MFIs are operated by NGOs who are not much interested in profit-making and their goal is to offer loans to the poor under flexible and relaxed repayment terms. Most of the MFIs in Zimbabwe are privately owned by individuals who are profit-oriented and this is seen the enforcement of short repayment period, attached with a high-interest rate of borrowing which further push them into poverty (Liñares-Zegarra \& Wilson, 2018; Mpofu et al., 2013; Mushtaq \& Bruneau, 2019).

Studies on the effectiveness of microfinance have gained much attention over the years and results from previous studies show bases of structural weakness at several levels, wastage, 
and inefficiencies among MFIs. So far a tailored framework to suit the operational environment of MFIs in economies with low-income earners who are considered risky by traditional banks, (Abor, 2016; Fall et al., 2018; Sanfilippo-Azofra et al., 2019; UN, 2013). In this view, we can see that the main goal of these organizations, is to stay in business and also been profitable, irrespective of the challenges and the level of risk existing in the financial system (Moyo, 2018; Tapera \& Mbira, 2016).

In the opinion of (Ariffin, 2012) in a study on Islamic banks in Malaysia, concluded that disclosure of a company's risk management positions and strategies is essential to improving transparency and corporate governance for market participants. Also, a study on Zimbabwe MFIs, (Mago et al., 2013) agreed that microfinance institutions have limited capacity to manage operational risks, transaction risk, fraud, and legal risk. This should be further supported by the government through an effective regulatory environment and policies which are favorable, (Song \& Xiong, 2018; Tapera \& Mbira, 2016).

\subsection{Contribution of MFI in Zimbabwe and Developing Countries}

The role of the microfinance sector in an economy has received considerable attention, for instance, (Gallagher \& Muzorewa, 2017) concluded that Peru through a dynamic informal sector was able to stabilize and develop its economic development using a well-defined and well-structured microfinance sector. MFIs are mostly seen promoting economic growth when the total factor productivity is increased, (Agbola et al., 2017; Brière \& Szafarz, 2015; Donou-Adonsou \& Sylwester, 2017; Gallagher \& Muzorewa, 2017; Mago, 2014a, 2014b).

Growth of the industry through sustainable development in Zimbabwe has been a result of the microfinance board which host training programs, and technical skills programs for MFIs, banks, and NGOs who are aiming to serve farmers, youth, workers and those small enterprises (Donou-Adonsou \& Sylwester, 2017; Moyo, 2018; ZAMFI, 2018). This move clearly shows that these MFI are not only having the need to meet the immediate needs of households or the working class but also aims at assisting the agribusiness and energy sectors within the economy.

\section{Theoretical Framework and Hypothesis}

It has been evident in Zimbabwe that households (salaried workers) need cash from their banks for daily needs, but their banks and agents are not in a position to supply the households with their cash as to when they require the cash due to liquidity shortages. There are two possible reactions to a cash shortage: currency emission or limiting of cash payments. The first is to eliminate the cash shortage, and the second is to adjust the payment plan to accommodate the shortage and transfer the cash shortage to the households. In cash-shortage countries, there are two payment adjustments: either government organizations delay payment of salaries or they are crediting funds to household accounts in the banking system (Eldin \& Abdelrhman, 2018). While the banking system subsequently imposes restrictions on withdrawals (which must be limited in light of the cash shortage). These two approaches have been adopted in Zimbabwe.

$\mathrm{H}$ : Borrowing is mostly done for household use and not for investment reasons 
The inability of the banking system to meet the need to convert deposits into currencies, a process has known financial disintermediation; coincides with the second form of cash shortage: a shortage of the banking system, (Eldin \& Abdelrhman, 2018). In agreement with the theory, individuals in Zimbabwe are unwilling to deposit their funds in the banking system for circulation, instead, they hold the cash for future uses and sometimes even sell their cash to those who need it, in exchange of electronic money (in form of mobile money and bank transfers) at a higher price.

$\mathrm{H}$ : When loans are received there is no banking of the amount borrowed

In an attempt to solve the cash shortages at the same time managing inflation, the use of electronic money was introduced and promoted as a better alternative of cash in the financial system, accompanied by reduction on transactions charges by the Central bank, (R.B.Z, 2016b) which was later removed by the government as they introduced a tax. This has now forced consumers to use tax-free cash since goods are now priced differently depending on the mode or method of payment.

H: Borrowers prefer money to be transferred as hard cash, not plastic money

With the desire to remain profitable while reducing bad debts in a risky financial system, credit services are currently extended to individuals who are employed in the formal sector and receive their salaries either monthly or fortnightly. With this loan application requirement criteria in use, this has made the funds to be available mostly for government workers. Moreover, loan approvals and amounts are based on the applicant's qualifications and debt capacity, which depends on several factors, that might be either be personal or business characteristics, such as age, gender or reputation, source of income and amount of income, business age (if any), cash flow and available guarantees, (Ledgerwood, Earne, \& Nelson, 2013).

H: Loans are based on a civil servant's salary and not on their other sources of income

H: Loans are attached to salary as collateral security and not to any other asset

\section{Methodology}

\subsection{Data}

Given the nature and the unavailability of MFIs data in Zimbabwe, this study adopted the use of qualitative data, a combination of interviews, observations and MFI reports. (Abeysekera, 2019; Yin, 2009) commenting on case studies mentioned, data should come from six sources: files, archival records, interviews, direct observations, participant observations, and physical artifacts. The rationale behind using multiple data sources is that it improves data triangulation. Thus, we also adopted its methodology.

This study is exploratory, the use of semi-structured questionnaires, in-depth interviews were the most appropriate method. Thus, using in-depth interviews and observations data was obtained from key MFIs managers and loan issuing officers. This was to refine the theoretical framework and the hypothesis of our study. According to (Martin, Martin, \& Minnillo, 2009), 
the objective of an in-depth interview approach is to generate ideas on fewer research concepts that can guide theoretical development or future research; and, thus empirically validating future studies.

Primary and secondary data were collected. Primary data was collected using in-depth interviews and observations. Secondary data was gathered from company websites, product brochures, and government institution reports. For example, websites of institutions were visited to collect information involving distribution density and coverage of MFIs. Additionally, some MFIs provided product brochures which indicated: pricing of loans, repayment, and loan terms that were relevant to our study. Thus, data from different sources improved data triangulation in our study.

A single semi-structured questionnaire was used to collect data. The questions were solely based on the research aim and objectives. Thus, interviewing the MFI officials was appropriate, since researchers were able to make additional observations as well as collect both verbal and nonverbal information. Therefore, making it possible to determine whether there is a difference between what the respondent said and what is happening. This process was followed since it was used by other studies, (Abeysekera, 2019; Johnsen \& Ford, 2006).

\subsection{Sample Selection and Sample Size}

In this view, a non-probability sampling method targeting MFIs in the capital city, Harare was considered, because that is where $78 \%$ of the MFIs are located. Moreover, no research to the best of our knowledge has considered MFIs in Harare as a sample filling the gap in previous studies (Dube \& Matanda, 2013; Mago, 2014b; Mago et al., 2013; Mpofu 2018; Mpofu et al., 2013; Tapera \& Mbira, 2016; Tshuma \& Selome, 2014) who focused on other areas. That is, out of 160 registered MFIs in Harare, 186 responses were obtained purposively from 98 institutions in business for 3 years and above.

\section{Discussion of the Findings}

Testing our hypothesis of whether loans are based on a civil servant's salary and not on their other sources of income. Our study reveals that the loans given and offered by MFIs are either salary-based or some forms of securities are required before an applicant can access the loan. This result is directly linked to the repayment terms set by most of the microfinance institutions in which: a current payslip, confirmation of employment and a valid stamped bank statement, are the main key requirements that guarantee if the loan application will be successful or rejected in the first place for government workers. Furthermore, an additional document is required in the case of nongovernment workers (private sector employees). Thus, a memorandum of understanding $(\mathrm{MoU})$ between the microfinance institution and employer must be agreed upon before the loan applicant is considered for the loan application.

Our study point to the fact that the documentation needed for a loan application by MFIs make it easier for government workers to access loans since all the items required are readily available for them compared to private firms was their employer might not be willing to sign an $(\mathrm{MoU})$ due to the uncertainty in the business environment. Also, in the case that the employer agrees, conflict might arise on the amount the employer might be willing to 
guarantee on behalf of the employee; and, in the case that the business is not performing well financially, the employer too might not be willing to be part of the MoU agreement. Hence, the need for MFIs not to just focus on households and beneficiaries of their services, but beyond just measuring the direct effects of borrowers and direct beneficiaries, (Alimukhamedova, 2019).

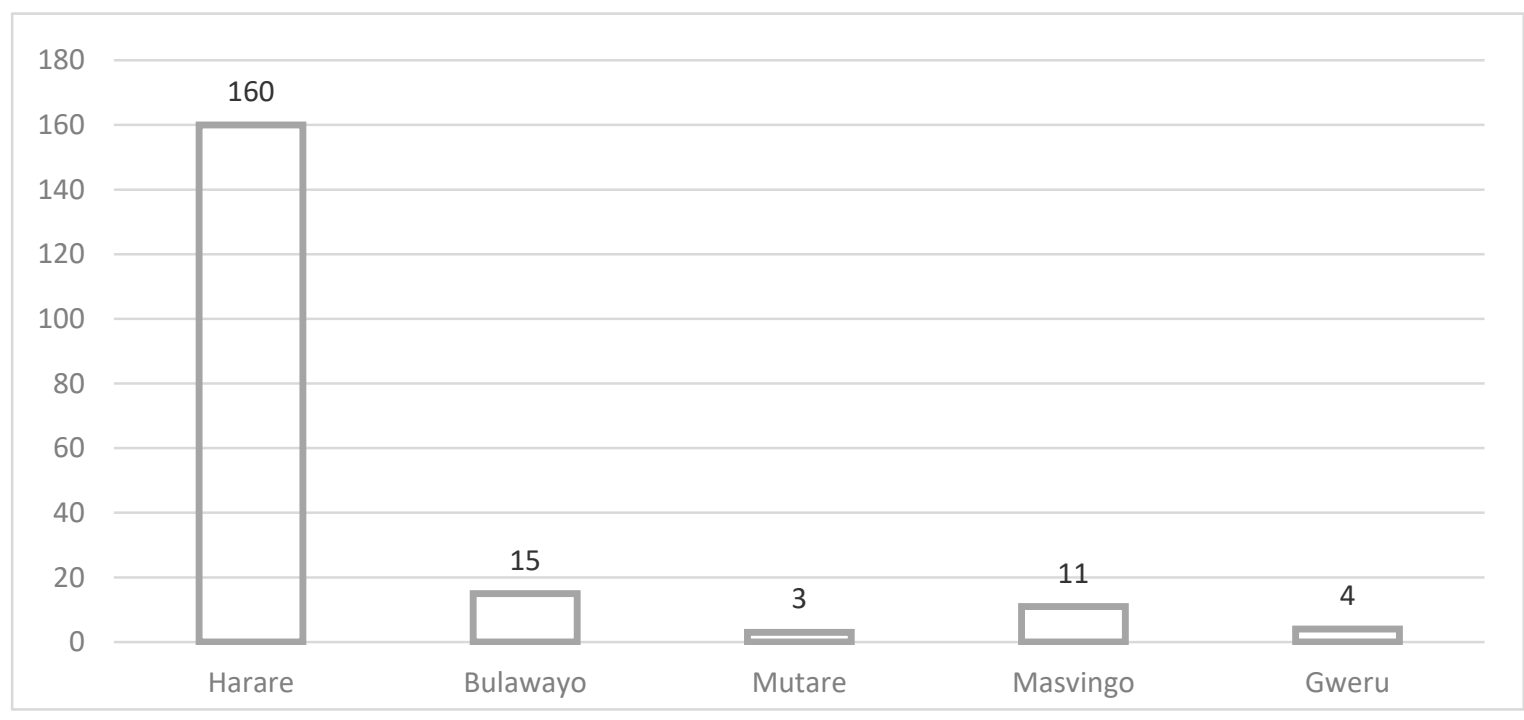

Figure 2. Distribution density of MFIs across towns and cities in Zimbabwe

As shown in Fig 2 which shows the distribution of MFI across cities and towns as of 2018, show that 78\% (160) operates in the capital, while 7\% (15) operates in the second-largest city. In respective to size, smaller towns (Masvingo, Gweru, and Mutare) account for 6\% (11), 2\% (4), and 2\% (3) respectively. The result obtained might be the reason why most of the MIFs are mostly distributed in cities and towns as they are targeting households who are not just employed, but who also receive a certain level of basic income level. Thus, further supporting our previous assertion on MFIs being more of a salary or income-based when issuing loans to applicants.

Also, using the distribution density of MFIs in Fig 2, the growth of MFIs in Zimbabwe is increasing among the developed areas, not in rural areas. This study also affirms that MFIs have not been targeting the poor in villages and the unemployed. Their failure to offer loans to households in the villages has somehow hindered the growth of this sector. Commenting on the growth of MFIs, (Yimga, 2018) concluded that the rapid growth of microfinance has a positive impact on the cost per borrower, meaning that the faster the MFI expands, the higher the cost per borrower. Where microfinance growth is measured by adding more borrowers or increasing the loan sizes given. However, we affirm that MFIs have not been targeting the poor in villages and the unemployed due to several challenges existing in the economy. Though, as revealed by the responses made by MFIs representatives and managers, economic uncertainties and increasing risk exposure in the financial of the Zimbabwe sector have restricted the growth of MFIs across the country. In agreement with our result (Abor, 2016) mentioned, inadequate infrastructural support, lack of information and dissemination, high 
risk, inadequate funding; and, weak regulation and supervision as the constraints that hinder the functioning and growth of MFIs.

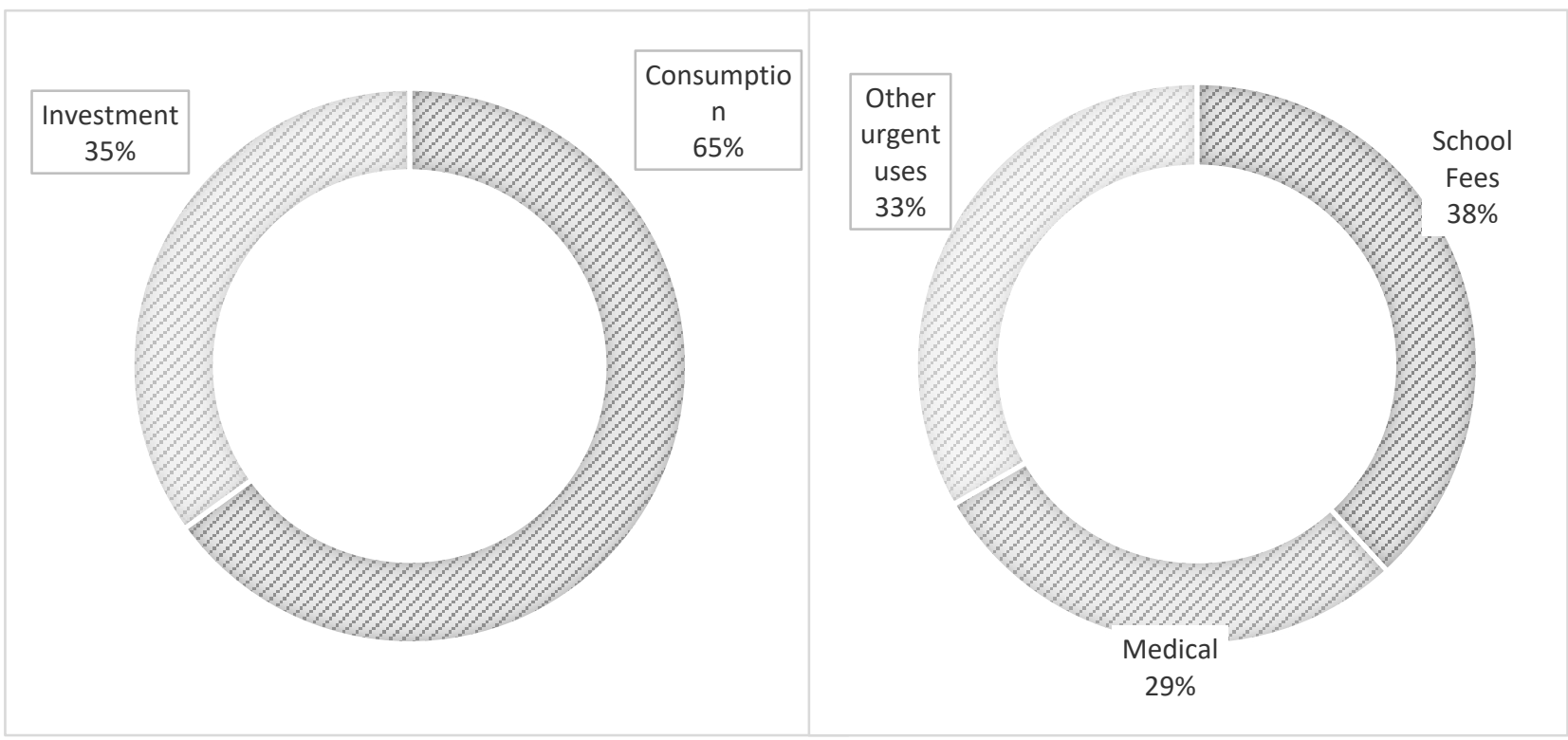

Figure 3. Reasons for loan application

Figure 4. Household uses of consumption loans

In an attempt to test if borrowing is mostly done for household use and not for investment reasons. Thus, when the MFIs representatives were asked whether the applicants of credit services were needed for consumption (personal) or business (investment) purposes. Their responses in Fig 3, we figured out that most loans applied and later were granted by the MFIs, consumption purposes accounted for 65\%; while, loan application for investment recorded $35 \%$. This outcome is in line with results obtained by (Dlamini \& Mbira, 2017) who revealed that the popularity and high usage of MFIs products and services were for consumption purposes and to cater for immediate needs in urban areas of Zimbabwe, a situation that is linked to liquidity crisis mostly referred to a financial meltdown caused by shortages in physical cash, loan funds, and banks running out cash.

Furthermore, our study extended its scope by inquiring about the major uses of consumption loans among households. The result (Fig 4) shows that $38 \%$ of the extra funds obtained from MFIs as loans were used for school fees funding, while $29 \%$ of such funds were used for medical expenses. Having households on a payroll (employed and receiving a stable income) not in a position to cover education and medical expenses among other basic needs, is a worrying sign of poverty among citizens. Moreover, in a proxy this level of poverty reached by the working class (employed households), therefore we can affirm strongly that, the poverty situation might be worse for those who are unemployed and not receiving any form of income, who cannot meet the requirements of MFIs loan application.

In the view of MFIs, a high-interest rate on loans is much beneficial to the institutions as it 
yields more returns in forms of profits. Our result in Table 1, clearly demonstrates challenges in the regulation of MFIs in Zimbabwe; were, majority of the MFIs impose an interest rate of between $11-21 \%$ and above on short term loans with a majority of them having less than 9 months of repayment duration. Thus, under normal circumstances, high charges on borrowing deter households to request for extra funding, however, due to income falling below the poverty datum line and the great need to cater for immediate expenses, households still borrow irrespective of the high cost of borrowing. Additionally, this result also illustrates regulation failures, as it is the duty and responsibility of financial sector regulators to effectively control and properly regulate, MFIs service and transaction fees (including the interest rate).

Table 1. Interest rate charged on loans

\begin{tabular}{|l|l|l|}
\hline Interest rate $(\%)$ & Frequency & Percentage $(\%)$ \\
\hline$<5.9 \%$ & 0 & 0 \\
\hline $6-10.9$ & 54 & 29.03 \\
\hline $11-15.9$ & 70 & 37.63 \\
\hline $16-20.9$ & 14 & 7.53 \\
\hline$>21 \%$ & 48 & 25.81 \\
\hline Total & $\mathbf{1 8 6}$ & $\mathbf{1 0 0}$ \\
\hline
\end{tabular}

Short loan term for personal use is an indication that households want funds for immediate expenses and their willingness to repay the loans with higher interest rate shows that the households are attempting to cover costs that are critical for their day to day living, to the extent that they cannot wait to receive their salaries, but wish to apply for highly-priced external funding from MFIs. As shown in Table 1, MFIs minimum threshold on interest rate falls between 6-10.9\% per period of 3 months repayment period; and, at an interest rate as high as $21 \%$ and above, households are still willing to access extra funding at such a price. This, therefore, making it difficult for households who borrow to stabilize their consumption levels since they are expected to settle the borrowed funds within the expected time thereby reducing the future month's consumption and increasing the likelihood to borrow again in the same MFI or another, to sustain their monthly consumption level.

Additionally, in other MFIs in the central business district, a 3 months loan term period had an interest rate of $25 \%$ added to the principal amount, while, education loans that need to be settled in 24 months had an interest on the borrowing of $2 \%$ compounded monthly. These inconsistencies and volatility in the interest rate, exchange rate among other macroeconomics factors make it difficult for institutions to offer long term loans which might affect the overall performance of the MFIs in the long run. In agreement with (Song \& Xiong, 2018) concluding on policy risk, mentioned that government policy interventions have important implications for the risks and effectiveness of the financial system; and, there are several main reasons for government intervention in the financial system. One of the critical reasons is that the financial system provides the financial instruments necessary for the government's 
policy agenda; and, the government's active intervention has had a profound impact on the financial system. Policies and regulations can have unintended consequences, some of which can be counterproductive.

Table 2. Amount offered by MFIs

\begin{tabular}{|l|l|l|}
\hline Amount $($ ZWL) & Frequency & Percentage (\%) \\
\hline$<800$ & 48 & 25.80 \\
\hline $801-1599$ & 24 & 12.90 \\
\hline $1600-2399$ & 40 & 21.50 \\
\hline $2400-3199$ & 37 & 19.90 \\
\hline$>3200$ & 37 & 19.90 \\
\hline Total & $\mathbf{1 8 6}$ & $\mathbf{1 0 0}$ \\
\hline
\end{tabular}

As already established in this study the issuing of loans by MFIs is based on salary (income) received, and also the amount given by the MFIs is of varying ranges depending on the income level. When the MFI representatives were asked whether there was a ratio or percentage (ratio of salary to loan) that they were using in issuing loans to either personal or consumption loans customers, some of the MFIs were in a position to offer loans between 6 and 10 times the basic salary of the applicant; while, other organizations used the total deductions charged on the applicant, to determine the actual amount that can be received as a loan by an applicant without causing financial stress on the borrower. This means that the higher the income level, the higher the chances of receiving higher funds as a loan. In reference to Table 2 we can allude that borrowers who received lesser funds as loans, their income levels influenced the amount granted by MFIs. However, these income-based loans are subjective to the deductions of the loan applicant; and, mostly exclude the unemployed, and households belonging to the informal sector will be financially excluded from the formal financial sectors. This situation will be a driving force for these excluded individuals to borrow from nonfinancial systems.

Table 3. Duration of loan payments

\begin{tabular}{|l|l|l|}
\hline Months & Frequency & Percentage (\%) \\
\hline $1-3$ & 50 & 26.87 \\
\hline $4-6$ & 44 & 23.66 \\
\hline $7-9$ & 34 & 18.26 \\
\hline $10-12$ & 28 & 15.10 \\
\hline$>13$ months & 30 & 16.11 \\
\hline Total & $\mathbf{1 8 6}$ & $\mathbf{1 0 0}$ \\
\hline
\end{tabular}

This assertion was further cemented by shorter loan terms duration (a period given to settle the principal and interest) accompanied by high borrowing rates imposed by the MFIs. For institutions that operate in smaller towns (growth points), an interest rate as high as $35 \%$ was 
imposed on loans with a once-off payment method (1 month payback period for both the principal and the interest) as in Table 3. However, high-interest rates, inadequate loan sizes, shorter loan repayment terms, and loan amounts are the major causes of loan default in Zimbabwe (Mpofu 2018), and this situation is detrimental for the MFIs performance in the economy. On the view of MFIs, a shorter loan term period is also an indication of how risky the financial market and the policy inconsistency concerning the introduction of new currencies and money supply policies by the central bank.

In testing whether borrowed funds were banked, current cash shortages, withdrawal cash limits, rising inflation, rapid introduction of new currencies and notes, and inconsistence in policies were some of the factors that led to the collapsing of the economy in 2008. Most of the factors evidence during that period are been witnessed a decade after the economic crisis, and the loss that stakeholders faced have to some extend made businesses and households to lose confidence and trust in most of the financial system policies reforms which lead to the holding of foreign currency during the multicurrency system when the local currency was reintroduced (bond coins and notes). This assertion agrees with (Dlamini \& Mbira, 2017; R.B.Z, 2016a; UN, 2013) who are of the view that public and investor confidence, country risk, and externalization of funds, illicit financial flows; thus, making strengthening of the legal framework a need for a developed the financial sector. On assessing the effectiveness of measures and policies put in place by the regulator after the economic meltdown of 2008, we observe that much still need to be done in an attempt to protect not only customers of MFIs; but, also the institutions.

Table 4. Summary of hypothesis results

\begin{tabular}{|l|}
\hline Hypothesis \\
\hline H: Borrowing is mostly done for household use and not for investment reasons - Accept \\
\hline H: When loans are received there is no banking of the amount borrowed- Accept \\
\hline H: Borrowers prefer money to be transferred as hard cash, not plastic money- Accept \\
\hline H: Loans are based on civil servant's salary and not on their other sources of income- Accept \\
\hline H: Loans are attached to salary as collateral security and not to any other asset- Accept \\
\hline
\end{tabular}

In reference to the hypothesis of this study; and, having established the fact that MFIs in Zimbabwe are offering loans that require little collateral on loans, in the form of payslip (salary/income-based). Basing on our results presented in Table 4, we, therefore, accept the mentioned hypothesis, as statements that have affected spending of households and thereby causing them to demand extra funding from the MFIs to cater for immediate expenses, which however point out a certain degree of poverty among the working class in Zimbabwe, especially civil servants who dominate among the working-class population.

\section{Conclusion}

This paper examines the purpose and rationale of MFIs establishments in Zimbabwe. Thus, in an attempt to understand the reason behind high borrowing, we also assessed loan terms, the nature of loans issued by MFIs, and the uses of borrowed funds among households. 
Investigating the loan application procedure of MFIs and using distribution density, our study examined the models practiced by MFIs in issuing loans.

The current study found out that the current cash shortages associated with household income falling below the poverty datum line and the economic sector instabilities in Zimbabwe have contributed to increased borrowing behavior of households from the MFIs. Further investigation in our study suggests that repayment terms requested by MFIs when applying for a loan is much favorable for civil servants (government workers), making it clear why most of the individuals who demand extra funding are government employees, and the loans they apply for mostly are for consumption purposes. Also, considering the consumption loan uses of the households, most of the short term loans are for school fees, medical and other immediate expenses is a clear indication that households demand loans for poverty eradication. (Tshuma \& Selome, 2014) suggested improving the impact of microfinance on poverty in Zimbabwe; and, we also affirm that access to MFIs services improved the economic position of households.

Our study being centered on urban areas, we expected that the loans granted by MFIs will be channeled towards investment, and growth of small businesses, as the main beneficiaries of these funds. However, these loans are predominantly given to salaried workers (employed households); and, utilized these funds for family consumption. This implies that, in the urban areas, overlooking investment: a factor which has the potential of eradicating poverty, restricts the long term benefits of poverty reduction among citizens. Hence, addressing the short term family liquidity challenges by the MFIs fails to address poverty in the long run.

Also, commenting on the connection that exists between interest and borrowing, we observed that the prevailing interest rates evidenced with shorter repayment period do not ensure financial stability among borrowers, thus failing to pull borrowers out of poverty, but create an interdependence syndrome of continuous borrowing of funds from the MFIs which are not meant for better future returns. That is, even though civil servants might have a better advantage in accessing MFIs loans in the long run, they are likely to remain in poverty since the purpose of borrowing is geared towards family expenses which are recurring and unending.

The prevailing cash shortages and the transactional tax imposed on all electronic money payments to some extend have influenced borrowers to demand loans in the form of cash. Thus, the economic meltdown in 2008 , contributed to the fact that both households and businesses prefer transacting in cash despite the cash shortages. This challenge is a true representation of stakeholders who does not have confidence in the financial system regimes.

Furthermore, we can mention that MFIs establishment in Zimbabwe is geared towards eradication of poverty. However, not targeting the poorest and the unemployed citizens in both cities and rural areas. Moreover, to some extent, the prevailing interest rates might have been a restricting factor among businesses in obtaining extra funding from MFIs.

This finding has important implications for most developing countries who have difficulties in recognizing microfinance as a point were development start. Hence, we recommend: 
- Effective regulation and monitoring of MFIs ensures institutional growth and better patronage of their services.

- Low investment in the short run affects the economic growth of the nation, in the long run, hence the need for a strong financial sector.

- A strong financial sector stimulates borrowing of funds channeled for investment (purchasing of machinery and equipment) which however contributes positively towards economic growth.

- To increase the living standards of citizens, MFIs should direct funds towards the production of goods and services.

- Regarding investment over household consumption will not only open opportunities for business growth but also employment and eradication of poverty among other things.

There are two major limitations in this study that could be addressed in future research. Firstly, the study focused on understanding the reason behind the growth of microfinance and a sudden increase of borrowing among salaried households, is one of a few studies conducted so far on civil servants (salaried workers), thus the sample size was limited by the availability of data, which however influenced the methodology used, but had no effect on the results obtained. Secondly, we suggest future studies to include samples from a greater geographic area or expanded to a multi-country analysis.

\section{Acknowledgement}

This study would not have been possible without the excellent support offered by managers and loan issuing officers of the sampled microfinance institutions in Harare.

\section{References}

Abeysekera, R. (2019). Business Development Services (BDS) offered by microfinance institutions (MFIS) in Sri Lanka: Case Study as a Research Strategy. Sri Lanka Journal of Management Studies, 1(1), 63-80.

Abor, J. Y. (2016). Entrepreneurial finance for MSMEs: A managerial approach for developing markets: Springer. https://doi.org/10.1007/978-3-319-34021-0

Agbola, F. W., Acupan, A., \& Mahmood, A. (2017). Does microfinance reduce poverty? New evidence from Northeastern Mindanao, the Philippines. Journal of Rural Studies, 50, 159-171. http://dx.doi.org/10.1016/j.jrurstud.2016.11.005

Alimukhamedova, N. (2019). What Happens When Microfinance Programmes Are Withdrawn? A Conceptual Framework for Analysing Causal Effects. 123-147. http://dx.doi.org/10.1007/978-3-030-05261-4_6

Ariffin, N. M. (2012). Liquidity risk management and financial performance in Malaysia: empirical evidence from Islamic banks. Aceh International Journal of Social Science, 1(2).

Banya, N., Toyana, M., Stonestreet, J., \& Boyle, J. (2019). Zimbabwe declares interim RTGS dollar its sole legal currency. Daily Maverick. 
Bayai, I., \& Ikhide, S. (2018). Financing Structure and Financial Sustainability of Selected SADC Microfinance Institutions (MFIs). Annals of Public and Cooperative Economics, 89(4), 665-696. https://doi.org/10.1111/apce.12207

Bhuiya, M. M. M., Khanam, R., Rahman, M. M., \& Nghiem, H. S. (2018). The relationship between access to microfinance, health-seeking behaviour and health service uses: Evidence from Bangladesh. Economic Analysis and Policy, 60, 9-17.

http://dx.doi.org/10.1016/j.eap.2018.08.004

Brière, M., \& Szafarz, A. (2015). Does Commercial Microfinance Belong to the Financial Sector? Lessons from the Stock Market. World Development, 67, 110-125. http://dx.doi.org/10.1016/j.worlddev.2014.10.007

Chakanyuka, M. (2019). Parly reviews microfinance laws. The Standard. [Online] Available: https://www.thestandard.co.zw/2019/04/07/parly-reviews-microfinance-laws

Copestake, J. (2019). Reframing Microfinance and Financial Inclusion Research: Case Studies and Synthesis. 163-173. http://dx.doi.org/10.1007/978-3-030-05261-4_8

Cull, R., Demirgüç-Kunt, A., \& Morduch, J. (2013). Banks and Microbanks. Journal of Financial Services Research, 46(1), 1-53. http://dx.doi.org/10.1007/s10693-013-0177-z

Dalu, T. (2018). Analysing the impact of the intermediary financial tranactional tax. [Online] Available: http://veritaszim.net/node/3322

Dlamini, B., \& Mbira, L. (2017). The Current Zimbabwean Liquidity Crisis: A Review of its Precipitates. Journal of Economics and Behavioral Studies, 9, 212-219. http://dx.doi.org/10.22610/jebs.v9i3.1760

Donou-Adonsou, F., \& Sylwester, K. (2017). Growth effect of banks and microfinance: Evidence from developing countries. The Quarterly Review of Economics and Finance, 64, 44-56. http://dx.doi.org/10.1016/j.qref.2016.11.001

Dube, H., \& Matanda, E. (2013). The Downfall of the Micro Lending Businesses in Zimbabwe: Causes and Remedies. International Review of Research in Emerging Markets and the Global Economy (IRREM) An Online International Research Journal, 487-499.

Eldin, S., \& Abdelrhman, S. E. D. (2018). From Hoarding to Holding: Dealing with Cash Shortage Crisis within the Context of Financial Repressed and High Inflation in Sudan.

Fall, F., Akim, A.-m., \& Wassongma, H. (2018). DEA and SFA research on the efficiency of microfinance institutions: A meta-analysis. World Development, 107, 176-188.

http://dx.doi.org/10.1016/j.worlddev.2018.02.032

Faruqee, R. (2010). Microfinance for agriculture in Bangladesh: Current status and future potential: Institute of Microfinance.

Gallagher, M. J., \& Muzorewa, S. S. C. (2017). The Economic Growth in Peru and the Economic Struggles of Zimbabwe. Journal of Business, Economics and Technology, 20(1), 19-27. 
InM. (2015). Institute of Microfinance. [Online] Available: http://inm.org.bd

Iqbal, S., Nawaz, A., \& Ehsan, S. (2019). Financial performance and corporate governance in microfinance: Evidence from Asia. Journal of Asian Economics, 60, 1-13.

http://dx.doi.org/10.1016/j.asieco.2018.10.002

Jain, B., \& Economics, R. I. (2009). Microfinance and the poorest. Paper presented at the First European Conference in Microfinance, Brussels.

Johnsen, R. E., \& Ford, D. (2006). Interaction capability development of smaller suppliers in relationships with larger customers. Industrial marketing management, 35(8), 1002-1015. https://doi.org/10.1016/j.indmarman.2006.05.005

Klinkhamer, M. (2009). Microfinance sector recovery study. np: Zimbabwe Association of Micro Finance Institutes and SNV Netherlands Development Organisation, Zimbabwe, 21201-23413.

Ledgerwood, J., Earne, J., \& Nelson, C. (2013). The new microfinance handbook: A financial market system perspective: The World Bank. https://doi.org/10.1596/978-0-8213-8927-0

Liñares-Zegarra, J., \& Wilson, J. O. S. (2018). The size and growth of microfinance institutions. The British Accounting Review, 50(2), 199-213.

http://dx.doi.org/10.1016/j.bar.2017.11.006

Mago, S. (2014a). Microfinance and poverty alleviation: An empirical reflection. Journal of Asian Finance, Economics and Business, 1(2), 5-13.

https://doi.org/10.13106/jafeb.2014.vol1.no2.5.

Mago, S. (2014b). Microfinance, Poverty Alleviation and Sustainability: Towards a New Micro-Finance Model for Zimbabwe. Journal of Economics and Behavioral Studies, 6(7), 551-560. https://doi.org/10.22610/jebs.v6i7.516

Mago, S., Hofisi, C., \& Mago, S. (2013). Microfinance institutions and operational risk management in Zimbabwe: Insights from Masvingo Urban. Mediterranean Journal of Social Sciences, 4(3), 159. http://dx.doi.org/10.5901/mjss.2013.v4n3p159

Makuyana, T. (2017). Some Aspects of the New Microfinance Law in Zimbabwe. Mediterranean Journal of Social Sciences, 8(3), 209-217.

http://dx.doi.org/10.5901/mjss.2017.v8n3p209

Martin, J. H., Martin, B. A., \& Minnillo, P. R. (2009). Implementing a market orientation in small manufacturing firms: from cognitive model to action. Journal of small business Management, 47(1), 92-115. https://doi.org/10.1111/j.1540-627X.2008.00263.X

Mashaya, B. (Producer). (2017). Biometric system for civil servants. Daily News [Online] Available:

https://www.dailynews.co.zw/articles/2017/10/06/biometric-system-for-civil-servants

Mhlanga, F. (2018). MFIs lending skewed towards consumption. Newsday. [Online] Available: https://www.newsday.co.zw/2018/12/mfis-lending-skewed-towards-consumption/ 
Moyo, A. (2018). RBZ registers 19 MFIs in six months. The Herald. [Online] Available: https://www.herald.co.zw/rbz-registers-19-mfis-in-six-months/

Mpofu , N. (2018). Causes and Impacts of Youth Loan Default in Micro finance Institutions in Matabeleland Zimbabwe. (Bachelor of Commerce Honours Degree in Economics.), Lupane State University.

Mpofu, S., Mutambanadzo, T., Oliver, C., \& Lungisani, M. (2013). Evaluation of the effectiveness of Zimbabwean micro-finance institutions in promoting entrepreneurs in Bulawayo: post dollarisation. Global Institute for Research and Education, 2(5), 12-17.

Munjenjema, S. (2017). Empower Bank capitalised. The Sunday Mail. [Online] Available: https://www.sundaymail.co.zw/empower-bank-capitalised

Munyanyi, W., Diza, M., \& Gumbo, L. (2017). Use of Plastic Money in Zimbabwe, Threats and Opportunities for Rural Communities. International Journal of Academic Research in Business and Social Sciences, 7(6), 354-366. http://dx.doi.org/10.6007/IJARBSS/v7-i6/2968

Mushtaq, R., \& Bruneau, C. (2019). Microfinance, financial inclusion and ICT: Implications for poverty and inequality. Technology in Society, 59, 101154.

http://dx.doi.org/10.1016/j.techsoc.2019.101154

Ndamu, S., \& Tatira, Z. (2016). Zimbabwe introduces bond notes. Newsday. [Online] Available: https://www.newsday.co.zw/2016/05/zimbabwe-introduces-bond-notes/

NewsDay. (2019). Bond notes and their possible long-term legacy. Newday. [Online] Available:

https://www.newsday.co.zw/2019/01/bond-notes-and-their-possible-long-term-legacy

R.B.Z. (2016a). Mid-term Monetary Policy Statement 2016. [Online] Available: www.rbz.co.zW

R.B.Z. (2016b). Press statement on reduction of charges on electronic transactions [Press release]. [Online] Available: www.rbz.co.zw

Samer, S., Majid, I., Rizal, S., Muhamad, M. R., Sarah, H., \& Rashid, N. (2015). The Impact of Microfinance on Poverty Reduction: Empirical Evidence from Malaysian Perspective. Procedia - Social and Behavioral Sciences, 195, 721-728.

http://dx.doi.org/10.1016/j.sbspro.2015.06.343

Sanfilippo-Azofra, S., Torre-Olmo, B., \& Cantero-Saiz, M. (2019). Microfinance institutions and the bank lending channel in Asia and Latin America. Journal of Asian Economics, 63, 19-32. http://dx.doi.org/10.1016/j.asieco.2019.06.001

Song, Z., \& Xiong, W. (2018). Risks in China's financial system. Annual Review of Financial Economics, 10, 261-286. https://doi.org/10.1146/annurev-financial-110716-032402

Tapera, J., \& Mbira, L. (2016). Key Success Drivers for Microfinance Institutions in Zimbabwe: Developing Core Competences for Financial Inclusion. International Journal of Business and Social Science, 7(3). 


\section{Macrothink}

Business and Economic Research

ISSN 2162-4860 2020, Vol. 10, No. 2

Tinarwo, R. (2016). An investigation into the challenges faced by small to medium enterprises in Zimbabwe: A case of Gazaland Market. Journal of Business and Management, 18(9), 148-153. http://dx.doi.org/10.9790/487X-180902148153

Tshuma, N., \& Selome, J. (2014). Microfinance and women empowerment in Zimbabwe: A case of women development fund in Umguza District. International letters of social and humanistic sciences, 35, 74-85. http://dx.doi.org/10.18052/www.scipress.com/ILSHS.35.74

UN. (2013). Microfinance in Africa: Overview and Suggestions for Action by Stakeholders. [Online] Available: https://www.un.org/en/africa/osaa/pdf/pubs/2013microfinanceinafrica.pdf

Yimga, J. (2018). Microfinance expansion and its effects on cost efficiency. The Quarterly Review of Economics and Finance, 69, 205-216. http://dx.doi.org/10.1016/j.qref.2018.03.006

Yin, R. K. (2009). Case study methods: Design and methods: Thousand Oaks: SAGE.

ZAMFI. (2018). Zimbabwe Association of Microfinance Institutions: Creating sustainable microfinance. [Online] Available: http://www.zamfi.org/

\section{Copyright Disclaimer}

Copyright for this article is retained by the author(s), with first publication rights granted to the journal.

This is an open-access article distributed under the terms and conditions of the Creative Commons Attribution license (http://creativecommons.org/licenses/by/4.0/). 